Article

\title{
Innovative Business Strategies in the Face of COVID-19: An Approach to Open Innovation of SMEs in the Sonora Region of Mexico
}

\author{
Luis Enrique Valdez-Juárez ${ }^{1, *(\mathbb{O} \text {, Mauricio Castillo-Vergara }}{ }^{2} \mathbb{C}$ and Elva Alicia Ramos-Escobar ${ }^{1}$ \\ 1 Department of Business and Economics Sciences, Technological Institute of Sonora Mexico, \\ Obregón 85000, Mexico; elba.ramos@itson.edu.mx \\ 2 Faculty of Economy and Business, Universidad Alberto Hurtado, Santiago 6500620, Chile; \\ mhcastillo@uahurtado.cl \\ * Correspondence: levaldez@itson.edu.mx; Tel.: +52-622-103-0253
}

Citation: Valdez-Juárez, L.E.;

Castillo-Vergara, M.; Ramos-Escobar, E.A. Innovative Business Strategies in the Face of COVID-19: An Approach to Open Innovation of SMEs in the Sonora Region of Mexico. J. Open Innov. Technol. Mark. Complex. 2022, 8, 47. https://doi.org/10.3390/ joitmc8010047

Received: 16 January 2022

Accepted: 15 February 2022

Published: 2 March 2022

Publisher's Note: MDPI stays neutral with regard to jurisdictional claims in published maps and institutional affiliations.

Copyright: (C) 2022 by the authors. Licensee MDPI, Basel, Switzerland. This article is an open access article distributed under the terms and conditions of the Creative Commons Attribution (CC BY) license (https:// creativecommons.org/licenses/by/ $4.0 /)$.

\begin{abstract}
The purpose of this study is to analyze and verify the effects of the business strategy (financial and market) and innovation management exerted on the economic indicators and business performances of SMEs in the south-central region of Sonora in Mexico. The effect of electronic commerce and the home office in the management of innovation and corporate performance is also analyzed. In addition, a multigroup analysis was carried out to check if there are significant differences between family and non-family businesses. The sample analyzed comprises 498 SMEs with between 6 and 250 employees in the commerce sector. To collect the information, a questionnaire was developed and applied to the online SME manager through the LimeSurvey Professional platform. The field work was carried out from February to October 2021. PLS-SEM was used for the data analysis. The results report that the business strategy (financial and market) does not have significant effects on the management of innovation and on the economic indicators of SMEs. On the other hand, innovation management has positive and significant effects on the economic indicators and business performance of SMEs. It is also revealed that economic indicators have a positive and significant effect on business performance. Open innovation strategies such as electronic commerce have positive and significant effects on innovation management and corporate performance. Similarly, the home office has significant effects on innovation management. Finally, unknown SMEs were found to be the best performers in innovation management and business performance. The study contributes to the development of the theory of competitive behavior and the theory of resources and capabilities.
\end{abstract}

Keywords: business strategy; innovation management; open innovation; SMEs

\section{Introduction}

Traditionally, in global society, cultural, technological, and economic changes increasingly affect the competitiveness of organizations [1,2]. However, there are external factors generated by problems related to health and/or diseases, which are little visualized in organizations by decision makers. In this case, there was the emergence of the COVID-19 disease caused by the new coronavirus known as SARS-CoV-2. This pandemic has caused serious health problems, which have permeated all business sectors due to restrictions on mobility and the physical contact of people from its emergence to the present. Since 2020, the International Monetary Fund and the World Bank have reported serious economic problems (recession) in most regions due to COVID-19 and assert that it is one of the worst economic crises since the one manifested from 1930 in the United States of America. In addition, the pandemic has affected the Latin American and Caribbean (LAC) region more significantly; according to data from the World Bank [3], COVID-19 has had a significant human cost, and its economic and social effects are being felt globally. To minimize these impacts, the World Bank [3] has declared and launched a combination of new projects, 
the restructuring of existing projects with emergency components, and the use of our disaster financing instruments. According to data from [4], the most serious problems that companies face are in supply chains and cash flows and in the impossibility of meeting the delivery dates of goods and services. In addition, a weak final demand for imported goods and services, an increase in risk aversion in financial markets, and a decrease in confidence in business can be seen. According to other relevant data of the OECD [4], in LAC the COVID-19 crisis has been a very strong blow to micro and small companies (SMEs) that do not have the necessary resources to absorb the impact. Up to 2.7 million businesses in LAC are likely to close, most of them micro businesses, representing a loss of 8.5 million jobs.

Faced with these difficulties and adversities, companies have had to adapt to external changes for their survival, through resilience and innovation (creative thought processes). Therefore, resilient companies adopt and execute innovation-based strategies to face the challenges from a holistic perspective, starting from the theory of competitive organizational behavior (a strategic perspective of the individual behavior of the entrepreneur) [5,6], where the effectiveness of the strategy depends on managerial capacities and the level of adaptation to constant market changes [7-9]. This is from a resource-based view (RBV) (a perspective of innovative capacity and financial resources focused on business reaction in order to compete locally and globally through the mix of tangible and intangible resources) $[10,11]$. Without a doubt, these strategic actions lead companies towards strong competitiveness and a substantial improvement in their financial performance. Therefore, our study aims to verify the main business strategies that affect the management of innovation and the financial results of SMEs in the Sonora region of Mexico. We define business strategy as a long-term plan to pursue specific performance advantages based on novel products, more efficient processes, or lower costs [12]. In addition, we try to investigate the effects of electronic commerce (e-commerce) and home office transactions, which affect the innovation management and corporate performance of SMEs.

Open innovation (OI) is defined as the use of intentional inputs and outputs of knowledge to accelerate internal company innovation [13], comprising multiple incoming and outgoing knowledge streams derived from purposeful interactions with others [14]. Open innovation is spreading across industries around the world; collective intelligence stimulates companies' open innovation, and companies improve their ability to innovate by integrating internal and external resources [15]. The adoption of OI by an organization means that its innovation management process improves, and ideas, concepts, designs, products, services, etc., flow in and out of its boundaries [16].

Open Innovation Communities (OICs) have become a crucial strategy for companies to bring together and engage geographically dispersed users to share knowledge and submit product-related ideas [17]. As information technology (IT) has spread to all industries, dynamic, open innovation capabilities that enable companies to "sense" and "seize" exit opportunities have become crucial [18], as the flows of information, technologies, and ideas are the basic elements of the innovation process [19]. The open innovation model includes various channels, such as the home office or electronic commerce [20]. While remote work used to be more a feature of multinational companies and open source communities, the pandemic forced millions of people across a wide range of industries to switch to working from home, literally overnight, prompting a struggle to adapt to remote collaboration [21].

Currently, under a pandemic scenario, these actions are considered to be disruptive innovations that strengthen business competitiveness [22]. The recent literature has scarcely studied the efficiency of business strategies and innovation management in SME-type companies, giving more space to large companies in the high-tech sector [22-25]. Therefore, this study is based on two complementary theories that help improve business competitiveness. On the one hand, there is the theory of competitive behavior where the entrepreneur makes strategic decisions through an approach based on leadership $[6,10,26]$, and on the other hand, there is the theory of resources and capabilities based on tangible and intangible elements that are transformed into innovative strategies to achieve competitive success $[6,26]$. Therefore, the behavioral and social phenomena that occur in the company 
are linked to business competencies for the execution of a competitive strategy based on resources and capabilities [10,11,27]. For several decades, and particularly in the current scenario, the behavior of SMEs has been the focus of study for researchers and experts in the business sciences. The business strategies deployed by SMEs to be more competitive require greater financial, technological, and managerial capacity to increase the innovation activities [27-29]. These barriers are deeper in SMEs located in emerging or developing economies. This study responds to the current problems of family and non-family SMEs with these unique characteristics. The actions and business strategies that the directors of these SMEs are developing are based on ambidextrous innovation (radical, incremental, and open innovation) for health and financial sustainability [29,30]. With the above context, the study tries to answer the following questions: (1) what are the key elements of business strategy and innovation management that raise the economic indicators and corporate performance of SMEs? (2) What are the strategic factors of e-commerce and the home office that raise the management of innovation and the corporate performance of SMEs?

This article has been structured as follows: the first part presents the theoretical review, the empirical review, and the development of the hypotheses. Then, the methodology used and the sample and its characteristics are explained, and the variables under study are justified. Finally, the results, discussions, conclusions, and future lines of research are shown.

\section{Literature Review and Hypothesis}

\subsection{Business Strategy (Market and Financial) and Innovation Management in SMEs}

Business strategy can be described as the behavior of a company in the market, including its policies, plans, and procedures [31]. Therefore, the strategy allows for a synchronization of the investments and activities of SMEs that are necessary for the development of innovation [32]. Business strategy is a useful summary indicator for evaluating companies' internal control strength, which is an important area for audit quality improvement among prospector-like clients [33]. Innovative capabilities are a consequence of the combination of business culture, resources, skills, and processes aimed at innovation [34]. For the innovation to be successful, financial and market strategies have to be identified [35]; an SME requires this combined strategy due to the limited resources and capacities it possesses [36]. Previous studies have widely recognized that a financial strategy results in increased investment in innovation and is one of the main causes of technological progress [37]. Moreover, the market strategy has a greater propensity to experience an innovation strategy [38]. Market orientation is consistent with the connotation of exploitation in the theory of organizational ambidexterity, that is, with emphasizing the improvement and innovation of products and processes [39]. In this sense, market-oriented companies with the capacity to innovate, focus on developing and implementing marketing skills and detecting a good market to improve their innovation [40]. The strategic objectives, as management instruments in small organizations such as SMEs, will allow them to develop their innovative capabilities [41]. Skills, learning, and organizational adjustments, together with technological innovation, determine the performance of a business, hence the relevance of the innovation process [42]. Given the theoretical context and the empirical argumentation, the following research hypotheses are proposed:

Hypothesis 1 (H1). With greater application of effective market and financial strategies, innovation management practices in SMEs are increased.

\subsection{Business Strategy in the Economy and Corporate Performance of SMEs}

Strategy is considered one of the main determinants of performance [43], and an important part of the literature on RBV capabilities has highlighted the value of developing organizational capabilities as a means of implementing company strategies [44]. The objective of a strategic decision is to make the best use of the skills and resources available in an organization in relation to the external variables to achieve the best possible 
performance [36]. From Penrose [45], strategic management research has postulated that the deployment of the capabilities that best serve to implement the strategic plans of the company produces both greater growth and better performance. The strategies are the policy and stance that an entity adopts in response to its competitive business environment and a set of values or product mix that it develops with the goal of outperforming competitors [46]. Studies affirm that the characteristics of the specific resources of the company lead to superior performance [47]. By implementing sustainability strategies, entrepreneurs can identify the value of current activities, assess what changes can be made to reduce negative impacts, and create activities that improve business performance [48] and sustain it for the needs of current and future generations [49]. These resources can be tangible or intangible [50-52]. Capabilities are also identified as tangible or intangible processes that facilitate the deployment of other resources and improve overall productivity [53]. Factors such as financial, organizational, marketing, technical, and reputational capabilities and resources have a direct impact on performance $[47,54]$. On the other hand, the dynamics of rapid change in the improvement and development of trading systems have an impact on improving performance, increasing liquidity and transparency, reducing risk, and increasing investment returns [55]. These have been reported in different ways in the literature: they decrease the risk of falling stock price [56]; improve the quality of earnings reports [57]; reduce irregularities in financial reporting [58]; mitigate bankruptcy risk [46]; and provide business continuity in a crisis [59]. Most empirical studies have shown how strategies in developed and emerging economies affect the performance of companies [60-64]. Consequently, the influence of business strategy is profound, fundamentally affecting the operations of companies and the design and implementation of their policies, including financial strategy, help in efficiently managing economic debt, productivity, and greater liquidity [38]. The literature provides various types of business strategy orientations, the most common being the focus on the relative emphasis a company places on the efficiency and/or effectiveness of a company's market position [65]. Furthermore, these events have led SMEs towards resilience, and they are undertaking strategies based on their financial and physical resources to minimize the effects of the global economic crisis [66,67]. Studies developed by Bodlaj et al. [68] and Felzensztein [69] report that SMEs with financial constraints motivate the development and adoption of marketing strategies for local and global markets and are more likely to encourage innovation. For this reason, SMEs with greater financial barriers develop greater creativity and innovation. On the other hand, Hewitt-Dundas [70] mentions that the financial strategies of SMEs with a limited budget can limit marketing strategies and require a greater use of resources and capabilities to reduce costs and take advantage of opportunities to increase the profit margin in the development of new products. This strategy, based on the maximization of resources, comes from managers and is dispersed throughout the organization (from top to bottom), promoting creativity and business innovation [71] The scarcity of financial resources and other inputs caused by the COVID-19 pandemic pushed SME managers to be more resilient and to encourage innovation to fight competitively. In addition, Grözinger et al. [72] show that SMEs can develop marketing strategies and innovative actions in normal economic environments and during economic crises. From the theoretical context and the empirical argumentation, the following research hypothesis is proposed:

Hypothesis 2 (H2). Greater application of effective market and financial strategies increases the economic indicators of SMEs.

Hypothesis 3 (H3). Greater application of effective market and financial strategies increases the results of the corporate performance of SMEs.

\subsection{The Management of Innovation and Its Effects on the Economy and Corporate Performance of SMES}

Some theories and history support the view that innovation is one of the main drivers of the economic growth and development of the world economy [73]. Innovation can be 
seen as the degree to which an organization generates, accepts, and implements new ideas, processes, products, or services [24]. Innovation capabilities are especially important in small companies because, for these companies, it is very difficult to compete in terms of costs, and innovation allows them to reduce costs or lower their prices or improve the quality or availability of their products [34]. The more grounded the innovation capacity controlled by a company, the more successful its performance [41]. The link between innovation management and SME performance has been extensively analyzed, and in most cases, it shows the existence of significant impacts on economic and business performance [74]. Strategic innovation management is concerned with the use of appropriate strategic management techniques and measures to maximize the impact of the company's innovation activities for business growth and performance [75]. In this same direction, Expósito and Sanchis-Llopi [76] reported that the introduction of innovation (product, process, and organization) can influence the performance of the SME, as measured by an increase in the company's sales and a reduction in its production costs. It also generates competitiveness and employment, not only in high-tech industries but in all sectors [77], and it has become a crucial factor that helps companies stay competitive and sustainable in the long term [78]. This is particularly true in emerging markets as companies are limited in obtaining other resources for strong growth $[79,80]$. Innovation is considered an effective means of keeping a company competitive, even when the company faces a management crisis [81]. However, the management of innovation processes in the business can be a problem faced by company managers due to the absence of a unified model of innovation-management processes in the company [28]. Companies that manage innovation outperform companies that do not in terms of productivity levels and economic growth [82], and in the modern economy, innovation is crucial for value creation, growth, and jobs [83]. Recent studies have revealed that resilient SMEs in the face of the pandemic have developed a wide variety of innovative actions and strategies (use of technology and new marketing schemes) that are driving them to compete locally and globally [25,84]. To face these competitive environments, which are full of uncertainty, SMEs adopt the ambidexterity of innovation with improvements and changes in products and processes from an incremental and disruptive context [25]. From the theoretical and empirical review, the following hypothetical approaches were structured:

Hypothesis $4 \mathbf{( H 4 ) . ~ G r e a t e r ~ e f f i c i e n t ~ p r a c t i c e s ~ i n ~ i n n o v a t i o n ~ m a n a g e m e n t ~ i n c r e a s e ~ t h e ~ e c o n o m i c ~}$ indicators of SMEs.

Hypothesis 5 (H5). Greater efficient practices in innovation management increase the corporate performance of SMEs.

\subsection{The Impact of Economic Indicators on the Corporate Performance of Companies}

Previous longitudinal research has indicated that increases in sales, market share, and market position positively impact a company results [44]. Indicators such as earnings and liquidity have an effect on performance [59]. Empirical evidence has been presented that shows that operating cash flow and return on investment affect company profitability [54]. The economic impacts of SME financing reveal a significant positive effect on business performance and employment [85]. The valuable dimension of resources allows a company to improve net income and reduce net costs, which, in other words, helps companies to seize an opportunity and minimize a threat [53]. Economic performance has been identified in many business surveys as the most important factor in determining the survival and growth of SMEs [86]. A study by the World Bank [87] indicates that economic results related to financing improve the performance and growth of companies by facilitating market entry, reducing risks, and promoting innovation and entrepreneurial activity in developing economies. In addition, economic indicators help to deepen the understanding of the various economic behaviors and make decision making more precise in order to affect performance [30]. On the other hand, recent studies indicate that SMEs currently 
require a greater cash flow and therefore are requesting bank support and loans to cover their daily operations and to invest in their marketing processes, actions that in the medium term can lead them to a strong indebtedness, affecting their financial health and thereby reducing their corporate performance [88]. With these antecedents presented, the following hypothesis is exposed:

Hypothesis 6 (H6). Better control of economic indicators allows the results of the corporate performance of the SME to increase. The theoretical model of the research exposes the close relationship that exists between all the constructs (competitive organizational behavior with resources and business capabilities) $[6,11]$. This literature-based model includes constructs that determine business competitiveness and corporate performance. Therefore, in response to threats and social phenomena inside and outside the organization, companies react and develop strategic actions. The deployment of resources and capabilities, such as financial strategies, market strategies, incremental innovation practices, and open innovation practices, allow companies to remain in global and highly competitive markets for longer periods. From the theoretical and empirical review, the following hypothetical approaches were structured (Figure 1).

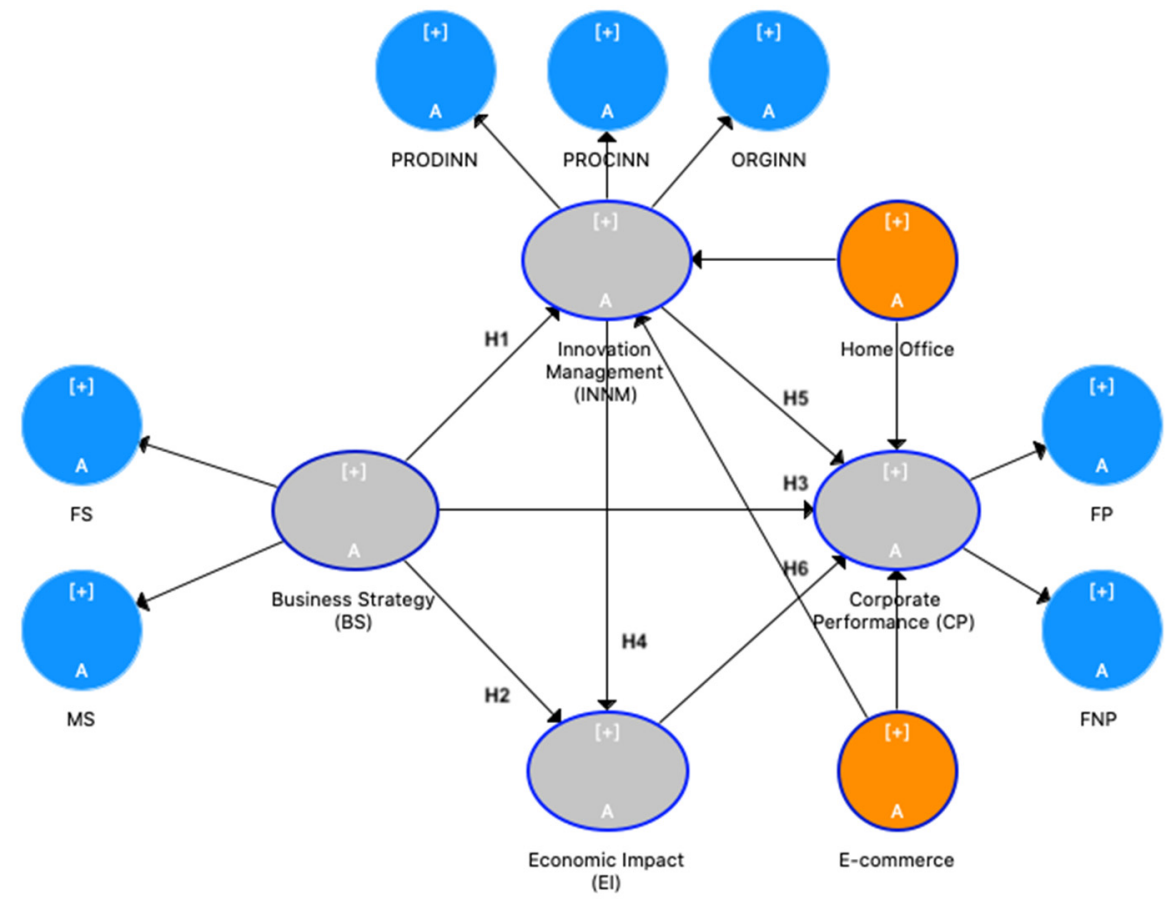

Figure 1. Nomogram of the study.

\section{Materials and Methods}

The study is based on the use of the Structural Equation Model (SEM) with the analysis of variance technique through the Partial Least Square (PLS). This statistical technique works with blocks of variables (components) and estimates the model parameters by maximizing the explained variance of all the dependent variables (both latent and observed) $[89,90]$. The research is quantitative and predictive in order to present and discuss new observations. The PLS-SEM statistical technique was chosen according to the objective of the research and the nature of the constructs of the operating model of this research. In addition, PLS-SEM has been used frequently for the analysis and perspectives in business strategic management and in other disciplines related to organizational performance [91]. This section describes the subjects (SMEs) participating in the study (sample), the questionnaire used, and its validation, as well as detailing the measurement of the constructs of the theoretical research model. 


\subsection{Sample}

The study is quantitative and predictive and the population of companies analyzed is divided by activity sector and size. The businesses selected for the study are geographically established in the central and southern region of the state of Sonora in Mexico. In this region, there are approximately 2982 micro, small, and medium commercial establishments with between 6 and 250 employees. The information on the total number of these companies was provided by the National Directory of Economic Units (DENUE) [92]. The sample size was determined so that the maximum margin of error for estimating a proportion was less than 0.04 points, with a confidence level of $95 \%$. The technique for collecting the information was through a personal interview (online questionnaire) directed to the owner and/or manager of the SME through the LimeSurvey Professional platform. The field work was carried out during the months of February to September of the year 2021. Finally, a sample of 498 surveys was obtained. Fifty-one percent corresponds to micro companies, $25 \%$ are small companies, and $22 \%$ are medium-sized companies. The management of these companies is represented by $33 \%$ women and $67 \%$ men.

\subsection{Questionnaire Validation}

To validate the questionnaire, an exhaustive review of the literature, a pilot test, and the statistical validation of the constructs were considered. For content validation, the most representative theorists who developed the constructs and metrics for measuring the variables under study were considered. A pilot test was launched for $3 \%$ of the total sample to verify the consistency and coherence of the items of each construct exposed in the questionnaire through a 5-point Likert scale. Regarding statistical validation, it was chosen to verify the non-response bias, through the variance of the common method. This type of analysis is highly recommended for instruments with variables that measure the behavior, aptitudes, values, or judgment of individuals [93]. For this study, we chose to analyze the variance of the common method with the Harman one-factor test [94,95]. This procedure is carried out through an exploratory factor analysis with all the variables of the model, considering the outputs of the matrix of unrotated factors. The results show that the model is grouped into 4 main factors with a KMO: 0.871, Bartlett Sphericity Test, significant at $99 \%$ and a total explained variance of $65.19 \%$. The first factor of the model that explains the dependent variable (entrepreneurial intentions) is $27.55 \%$, thereby ruling out the presence of non-response bias.

\subsection{Measurement of Variables}

The variables used in the research were measured through first- and second-order reflective one-dimensional variables in mode A. The SEM-PLS method was chosen for this research due to the following factors: (1) the nature of the items of a reflective type; (2) it adapts to the design of the quantitative-predictive type of research; and (3) the size of the sample and the robustness of the model with first- and second-order constructs [96]. Following the recommendations of Henseler [97] and Hair et al. [96], the constructs of this study and their indicators belong to the behavioral sciences as they analyze the actions and business behaviors of the leaders of SMEs. For this type of construct, the most appropriate form of measurement should be through a reflective type of model. This type of model assumes that the variance of a block of indicators (effects) is fully explained by an unobserved variable (the common factor) and its random errors. Measurement errors are assumed to be uncorrelated with the other variables, constructs, or errors in the model. The latent variable is not directly observable. Only the pattern of correlations between the indicators provides indirect support for their existence. The direction of causality is from the construct to the measures, and the indicators also share a common theme.

For the analysis of the multidimensional constructs (second-order) the two-stage approach was used. For this, the latent variable scores were analyzed. In the first stage, the aggregate scores of the first-order dimensions are estimated, and in the second stage, these aggregate scores are used to model the second-order construct [97,98]. To analyze 
the statistical data of the proposed theoretical model, the method based on variance was used through the SEM-PLS. The SmartPLS Professional version 3.3.5 software was used to analyze the measurement model and the structural model. The factorial loads of all the first- and second-order constructs were very close to and above the value of 0.707 [96] (see Appendix A).

\subsubsection{Business Strategy (BS)}

This variable was conceptually measured in a multidimensional way from the perspective of the theory of competitive organizational behavior [6] and resilient business management capable of reacting to frequent changes [99,100]. This variable was measured under two approaches: in the ability to implement market strategies (MS) associated with the introduction of new products and services to its clients and correct administration to guarantee the necessary resources [101] (measured with 3 items) [8,9] and under the financial strategies approach (FS) (measured with 3 items) [102,103]. These strategies are related to avoiding over-investment of the companies' cash flows and the creation of new projects that affect the liquidity of the business and that sometimes tend to adhere to unproductive investment policies [104]. The items of the questionnaire were designed under a 5-point Likert-type scale (1, completely disagree, to 5, completely agree).

\subsubsection{Innovation Management (INNM)}

This variable was measured in a multidimensional way with theoretical support in the models of the OECD [105] and Teece [106] as the superior strategy and key factor in detonating business capabilities in order to generate greater competitiveness and profitability [11]. The evaluation and analysis of problems can improve innovation processes and capacities [107]; a company that seeks to follow this strategy must participate in the development of new processes and propose an integrated offer of products and services to create value between companies and their customers [108]. The questionnaire collects responses from managers to indicate whether their SME had introduced innovation during the previous two years $(1=$ yes, $0=$ no) and the degree of importance on the innovative activity. For this, a scale is used (Likert-type of 5 points with $1=$ not important and 5 = very important): (1) Innovation in products (PRODINN), measured with 2 questions; (2) Innovation in processes (PROCINN), measured with 2 items; and (3) Organizational innovation (ORGINN), measured with 3 items.

\subsubsection{Economic Impact (EI)}

This variable was measured in a unidimensional way from the conceptual point of view, based on the factors of the competitive success of a company. The studies of the OECD [109] and the World Bank [3] have been taken as a reference to design the items to measure this construct on the financial health of the SME. For this, the managers reported in the questionnaire on the economic impacts generated in the last 2 years. This variable was measured through six items: (1) the impacts in the billing level, (2) profitability, (3) productivity, (4) the impacts in the realization of investments, (5) the level of debt, and (6) the level of liquidity. For this, a scale is used (Likert-type of 5 points, with $1=$ not important and 5 = very important).

\subsubsection{Corporate Performance (CP)}

Objective performance measures, such as return on assets, return on sales, and return on equity, have had inherent problems due to having a short-term focus, not adjusting to risk, and being difficult to relate to a specific innovation [110]. Accounting measures are also based on historical costs and, therefore, may not accurately reflect the future [111]. In this study, the managers answered questions to classify corporate performance results based on financial performance results and measured with 4 items: (1) customer satisfaction, (2) adaptation to changes in the market, (3) speed of sales growth, and (4) increased profitability. Regarding the non-financial performance, it was measured with 3 items: 
(1) efficiency of production processes, (2) employee satisfaction, and (3) degree of work absenteeism, using a 5-point Likert-type scale with $1=$ poor performance in the previous 2 years and $5=$ high performance in the last 2 years. This variable was measured with 4 items adapted from Quinn [112] and Aras et al. [113].

\subsection{Control Variables}

In this section, two control variables (home office and electronic commerce) have been included in the proposed theoretical model to verify whether they have an effect on innovation management and corporate performance. In general, the inclusion of these variables in the research models strengthens them and leads to greater empirical conclusions $[96,114]$.

\subsubsection{Home Office}

Home office or teleworking is not a recent practice; however, in the last two years it has increased exponentially in most companies, and in SMEs, it is no exception. From a technical point of view, teleworking is mainly characterized by the distribution of its components, the terminal at home (computer equipment) and at the office, connected through telecommunications services [115]. So, teleworking is an alternative strategy with variable work time and in different workplaces, which can lead to savings and minimize costs in the company [116]. For this study, the managers of the SMEs were asked if in the last 2 years they had adopted the home office strategy for the development of work activities in their company during COVID-19. This variable was considered a dummy, because the value of 0 was given to the companies that had not implemented the home office and the value of 1 for those that had.

The shift of workers to work from home has led to a significant result: many professionals in the labor market have developed new work and communication skills at an enormous pace and scale, thereby increasing their professional competitiveness at the local level, the national level, and, for some, even the worldwide level. This change is a leap towards higher quality virtual collaboration and better conditions for open innovation [117]. This is why the relationship between collaboration and innovation performance also applies when it comes to partnerships over greater distances [118]. Telecommuting can include the identification of goals, tasks, milestones, and progress tracking without reporting being too onerous, allowing employees the flexibility and autonomy to work; this can enable sharing and being more creative [119]. In the time of the COVID-19 crisis, organizations and individuals are becoming extraordinarily creative in finding new solutions. This is where the true exponential power of convergence is being found when different objects, technologies, disciplines, companies, industries, or talented people come together [25].

\subsubsection{E-Commerce}

From a conceptual point of view, electronic commerce is defined as the purchase and sale of any product or service that is carried out through the internet [120]. For SMEs, this business strategy is an action that generates competitive advantage and profitability [121]. For this study, this variable was considered as a dummy as the SME managers were asked if they had adopted electronic commerce during the last two years to face the COVID-19 pandemic. A value of 0 was given to companies that had not adopted electronic commerce and a value of 1 for those who answered that they had.

Companies running e-commerce rely on the use of open innovation to stay abreast of changes in consumer demand and technology [122]; this open innovation must be based on the development of open innovation projects that integrate external knowledge through social networks and digital platforms [19]. These tools cover a wide spectrum of needs ranging from knowledge sharing, sharing and tagging, to social networking, group creation, mind mapping, and discussion. Facebook and LinkedIn are representative examples of social networking tools that facilitate the formation of online communities among people with similar interests [16]. For years, companies have collected user input for product development, including suggestions for new products and advice on developing existing 
models. Vendors have often been tasked with collecting user feedback for use in the product development process. Technological advances, especially the internet, allow the acquisition of knowledge from a large population [123].

In the context of electronic commerce, consumer demands and technological changes require online businesses to be at the forefront of technological innovation and to continuously explore new innovation practices that cross their borders [13]. Feedback refers to the comments of other users on previous ideas generated by a particular user in OI; this feedback can serve as structural or procedural knowledge to help users interpret, reformulate, and reframe the problem-related generation processes and the implementation of ideas, such as understanding the constraints or key issues and allowing people to generate a high-quality idea [17]. On an internet-based platform, collaboration with external agencies, such as clients or other companies, is increasing; the greater the connection of an individual, the greater is their participation in innovation [18].

\section{Results}

This section reports on the results of the investigation through the PLS-SEM technique. To do this, the measurement model is first analyzed and then the structural model later. In addition, a multi-group analysis was carried out to deepen and strengthen this research.

\subsection{Measurement Model}

For the reliability and validity of the constructs, the analysis of the following reliability indicators was considered: Cronbach's alpha (CA), rho_A, composite reliability (CR), convergent validity, and discriminant validity. The reliability indicators of all our values are above 0.8 , the parameters recommended by [96]. In addition, it was also observed that the convergent validity through the analysis of the mean variance extracted in all the constructs exceeded the value of 50\% [124]; see Table 1 .

Table 1. Reliability and validity of the constructs.

\begin{tabular}{ccccc}
\hline Construct & CA & rho_A & CR & AVE \\
\hline Business Strategy (BS) & 0.807 & 0.808 & 0.862 & 0.510 \\
Innovation Management (INNM) & 0.913 & 0.915 & 0.931 & 0.659 \\
Economic Impact (EI) & 0.864 & 0.901 & 0.895 & 0.587 \\
Corporate Performance (CP) & 0.899 & 0.900 & 0.921 & 0.624 \\
\hline
\end{tabular}

The amount of variance that a construct captures from its indicators (AVE) must be greater than the variance that said construct shares with the other indicators of the model (squared correlation between the two constructs). For there to be discriminant validity, according to the Fornell and Larcker criterion, the square root of the AVE (the values on the diagonal are the square root of the shared variance between the construct and its measures) of a construct must be greater than the correlation that you have with any other construct [91,125] (see Table 2).

Table 2. Discriminant validity of the model: Fornell and Larcker criterion.

\begin{tabular}{|c|c|c|c|c|c|c|c|c|c|c|c|}
\hline Constructs & BS & $\mathrm{CP}$ & EI & FNP & FP & FS & INNM & MS & ORGINN & PROCINN & PRODINN \\
\hline BS & 0.714 & & & & & & & & & & \\
\hline $\mathrm{CP}$ & -0.058 & 0.790 & & & & & & & & & \\
\hline EI & 0.057 & 0.133 & 0.766 & & & & & & & & \\
\hline FNP & -0.010 & 0.925 & 0.121 & 0.858 & & & & & & & \\
\hline $\mathrm{FP}$ & -0.091 & 0.952 & 0.128 & 0.764 & 0.827 & & & & & & \\
\hline FS & 0.869 & 0.003 & 0.065 & 0.034 & -0.023 & 0.806 & & & & & \\
\hline INNM & 0.058 & 0.427 & 0.189 & 0.417 & 0.389 & 0.085 & 0.812 & & & & \\
\hline MS & 0.883 & -0.102 & 0.035 & -0.051 & -0.133 & 0.534 & 0.018 & 0.825 & & & \\
\hline ORGINN & 0.045 & 0.406 & 0.167 & 0.407 & 0.361 & 0.072 & 0.934 & 0.009 & 0.907 & & \\
\hline PROCINN & 0.062 & 0.376 & 0.223 & 0.371 & 0.340 & 0.070 & 0.914 & 0.039 & 0.781 & 0.870 & \\
\hline PRODINN & 0.054 & 0.371 & 0.127 & 0.343 & 0.354 & 0.091 & 0.863 & 0.006 & 0.676 & 0.740 & 0.898 \\
\hline
\end{tabular}


In order to strengthen this section, we have added another discriminant validity test through the analysis of the heterotrait-monotrait ratio (HTMT). This indicator represents the average of the heterotrait-heteromethod correlations in relation to the average of the monotrait-heteromethod correlations [97] (see Table 3).

Table 3. Discriminant validity of the model (HTMT).

\begin{tabular}{ccccc}
\hline Constructs & BS & CP & EI & INNM \\
\hline BS & & & & \\
CP & 0.126 & & & \\
EI & 0.101 & 0.145 & 0.191 \\
INNM & 0.093 & 0.471 & \\
\hline
\end{tabular}

\subsection{Structural Model}

To analyze the structural model, the algebraic sign $(+,-)$, the magnitude, the value of $t$, and, finally, the level of significance of the trajectory coefficients (beta value) are evaluated. This analysis was carried out through the bootstrapping resampling technique with 5000 samples. In addition, standard deviation and explained variance $\left(\mathrm{R}^{2}\right)$ are shown by multiplying the value of the path coefficient and the correlation. This analysis was performed under a one-tailed Student's t distribution with n-1 degrees of freedom.

The results of the hypothesis test of the research model are reported in Table 4 . In them, it can be seen that there is empirical support for $\mathrm{H} 3, \mathrm{H} 4, \mathrm{H} 5$, and H6; all these structural relationships manifest a significant effect. However, empirical support could not be established for $\mathrm{H} 1$ and $\mathrm{H} 2$. On the other hand, Table 5 shows the results of the control variables introduced in the model. The results reveal that e-commerce has positive and significant effects on innovation management and on the corporate performance of SMEs. Furthermore, it can be observed that the home office only has positive and significant effects on the innovation management of SMEs in this region.

Table 4. Model Hypothesis Test.

\begin{tabular}{|c|c|c|c|c|c|c|c|c|c|c|c|}
\hline Hypothesis & Path Coefficient & SD & T Value & $p$ Value & $\mathrm{F}^{2}$ & $\begin{array}{c}\text { Explained } \\
\text { Variance }\left(R^{2}\right)\end{array}$ & $\begin{array}{l}\text { Percentile } \\
5 \%(\mathrm{CI})\end{array}$ & $\begin{array}{l}\text { Percentile } \\
95 \% \text { (CI) }\end{array}$ & $\begin{array}{l}\text { Bias-Corrected 5\% } \\
\text { (CI) }\end{array}$ & $\begin{array}{l}\text { Bias-Corrected } 95 \% \\
\text { (CI) }\end{array}$ & Result \\
\hline H1: (BS) -> (INNM) & 0.057 n.s. & 0.052 & 1.103 & 0.135 & 0.003 & $0.33 \%$ & -0.032 & 0.143 & -0.031 & 0.142 & Rejected \\
\hline H2: (BS) -> (EI) & 0.046 n.s. & 0.044 & 1.030 & 0.151 & 0.002 & $0.29 \%$ & -0.030 & 0.119 & -0.028 & 0.116 & Rejected \\
\hline $\mathrm{H} 3:(\mathrm{BS})->(\mathrm{CP})$ & $-0.086 * *$ & 0.045 & 1.922 & 0.027 & 0.009 & $0.49 \%$ & -0.160 & -0.014 & -0.159 & -0.013 & Confirmed \\
\hline H4: (INNM) -> (EI) & $0.186^{* * *}$ & 0.046 & 4.062 & 0.000 & 0.036 & $3.54 \%$ & 0.108 & 0.260 & 0.110 & 0.259 & Confirmed \\
\hline H5: (INNM) -> (CP) & $0.421 * * *$ & 0.043 & 9.767 & 0.000 & 0.211 & $17.98 \%$ & 0.349 & 0.489 & 0.347 & 0.490 & Confirmed \\
\hline H6: (EI) $>>(C P)$ & 0.059 * & 0.039 & 1.501 & 0.067 & 0.004 & $0.80 \%$ & -0.006 & 0.121 & -0.005 & 0.124 & $\begin{array}{c}\text { Partial } \\
\text { Confirmed }\end{array}$ \\
\hline
\end{tabular}

Table 5. Results of the effect of the control variables.

\begin{tabular}{ccccc}
\hline Structural Relationship & Path Coefficient & SD & T Value & $p$ Value \\
\hline E-commerce -> Corporate Performance (CP) & $0.172^{* * *}$ & 0.040 & 4.321 & 0.000 \\
E-commerce -> Innovation Management (INNM) & $0.158^{* * *}$ & 0.048 & 3.304 & 0.000 \\
Home Office -> Corporate Performance (CP) & 0.030 n.s. & 0.043 & 0.707 & 0.240 \\
Home Office -> Innovation Management (INNM) & $0.143^{* * *}$ & 0.041 & 3.482 & 0.000 \\
\hline
\end{tabular}

*** $p<0.001 ;$ n.s.: not significant.

\subsubsection{Indicators of Predictive Analysis of the Model}

To verify the predictive quality of the theoretical model, the adjusted $r^{2}$ value of the endogenous constructs was analyzed; the results report the following: INNM $=0.040$, $\mathrm{EI}=0.034$, and $\mathrm{CP}=0.213$. These results report that $\mathrm{CP}$ as the dependent variable has a moderate predictive power and effect $[126,127]$. The effect size of the exogenous to the endogenous variables of the model was also analyzed through the $\mathrm{f}^{2}$ test. The data reveal that the 
key relationships of the model are: INNM $->\mathrm{CP}=0.211$ (mean effect); INNM $->\mathrm{EI}=0.036$; $\mathrm{BS}->\mathrm{CP}=0.009$; $\mathrm{EI}->\mathrm{CP}=0.004$; $\mathrm{BS}->\mathrm{INNM}=0.003$; and $\mathrm{BS}->\mathrm{EI}=0.002$, (all these relationships show a small effect) $[89,128]$.

\subsubsection{Measuring the Predictive Relevance of the Model}

To evaluate the model's predicative relevance, the Stone-Geisser test was carried out using the blindfolding technique to determine the value of $\mathrm{Q}^{2}$. Values of the reflective variables greater than zero are considered to have adequate predictive relevance $[89,96]$. Our model results show the following values: $\mathrm{INNM}=0.030, \mathrm{EI}=0.0 .018$, and $\mathrm{CP}=0.135$. In addition, another measure of goodness of fit was incorporated to measure the global model; for this, the Standardized Root Mean Square Residual (SRMR) was considered, a value that must be below 1 [129]. Our value is 0.080 , which shows that the proposed model has a good fit.

\subsection{Multi-Group Analysis}

This analysis allows you to test whether the predefined data groups have significant differences in the estimates of their group-specific parameters (for example, external weights, external loads, and path coefficients). SmartPLS provides results from three different approaches that are based on the boot results from each group. In this study, a nonparametric PLS-MGA analysis was used; this test requires confirmation of the measurement invariance between two groups. The groups analyzed are: G1 = non-family businesses (34\% of the total sample) and G2 = family businesses (66\% of the total sample). For this purpose, the configurational invariance and the compositional invariance were analyzed. The configurational invariance confirmed that in the treatment for the measurement of the data of the two groups, differences in the structure and design of the constructs do not exist. For compositional invariance, a permutation method was used with a sample of a minimum of 1000 permutations with a significance level of 5\% [130]. This method compared the correlations of the original score with the empirical distribution correlations after the permutation process. The values of the correlations are very close to the value of 1 , except for the Economic Impact (EI) construct; see Table 6.

Table 6. Configurational invariance.

\begin{tabular}{|c|c|c|c|c|c|}
\hline Configurational Invariance & Original Correlation & Permutation Means Correlation & $5.00 \%$ & Permutation $p$-Values & Results \\
\hline Business Strategy (BS) & 1.000 & 1.000 & 0.999 & 0.633 & Yes \\
\hline Corporate Performance (CP) & 1.000 & 1.000 & 1.000 & 0.585 & Yes \\
\hline E-commerce & 1.000 & 1.000 & 1.000 & 0.217 & Yes \\
\hline Economic Impact (EI) & 0.394 & 0.970 & 0.922 & 0.004 & No \\
\hline Home Office & 1.000 & 1.000 & 1.000 & 0.203 & Yes \\
\hline Innovation Management (INNM) & 1.000 & 1.000 & 1.000 & 0.186 & Yes \\
\hline
\end{tabular}

In Table 7, the mean values of the constructs are shown; in them, it can be observed that the data have a very similar behavior; that is, there are no significant differences between the values of group 1 and group 2 .

Table 7. Equality of means of the constructs.

\begin{tabular}{|c|c|c|c|c|c|c|c|}
\hline Constructs & $\begin{array}{l}\text { Average Original } \\
\text { Differences } \\
\text { G1/G2 }\end{array}$ & $\begin{array}{l}\text { Difference of Means of } \\
\text { Permutation G1/G2 }\end{array}$ & $5.00 \%$ & $95.00 \%$ & $5.00 \%$ & $95.00 \%$ & Equal Mean Values? \\
\hline Business Strategy (BS) & -0.007 & -0.002 & -0.150 & 0.156 & -0.184 & 0.170 & Yes \\
\hline Corporate Performance (CP) & 0.200 & -0.006 & -0.166 & 0.148 & -0.223 & 0.216 & Yes \\
\hline E-commerce & -0.193 & 0.002 & -0.148 & 0.167 & -0.305 & 0.313 & Yes \\
\hline Economic Impact (EI) & 0.078 & -0.007 & -0.164 & 0.141 & -0.223 & 0.200 & Yes \\
\hline Home Office & 0.059 & -0.003 & -0.148 & 0.145 & -0.145 & 0.125 & Yes \\
\hline Innovation Management (INNM) & 0.237 & -0.002 & -0.157 & 0.159 & -0.193 & 0.192 & Yes \\
\hline
\end{tabular}


Table 8 allows observing the results of the PLS-MGA test on the significant differences between G1 and G2; the structural relationships where these differences have occurred are in e-commerce -> (INNM) and home office $->(C P)$. Therefore, it can be inferred that electronic commerce actions in SMEs in this region are decisive for improving the efficiency of management innovation practices. In addition, this analysis reveals that the home office is a business strategy that has significant effects on corporate performance.

Table 8. PLS-MGA.

\begin{tabular}{|c|c|c|c|}
\hline Structural Relationship & Path Coefficient-Dif. (G1 vs. G2) & Original $p$-Value (G1 vs. G2) & New $p$-Value (G1 vs. G2) \\
\hline$(\mathrm{BS})->(\mathrm{CP})$ & -0.091 & 0.843 & 0.157 \\
\hline (BS) $->(\mathrm{EI})$ & -0.205 & 0.884 & 0.116 \\
\hline (BS) $->$ (INNM) & -0.109 & 0.845 & 0.155 \\
\hline E-commerce $->(\mathrm{CP})$ & -0.057 & 0.742 & 0.258 \\
\hline E-commerce -> (INNM) & 0.252 & 0.993 & 0.007 \\
\hline$(\mathrm{EI})->(\mathrm{CP})$ & 0.108 & 0.222 & 0.222 \\
\hline Home Office -> (CP) & 0.173 & 0.017 & 0.017 \\
\hline Home Office -> (INNM) & 0.037 & 0.334 & 0.334 \\
\hline (INNM) -> (CP) & 0.110 & 0.119 & 0.119 \\
\hline$(\mathrm{INNM})->(\mathrm{EI})$ & -0.207 & 0.964 & 0.036 \\
\hline
\end{tabular}

Table 9 reports the results of the PLS-MGA through the analysis of bootstrapping with one tail; the path coefficients show that G1 (non-family companies) have a greater strength in most of the structural relationships of the model with respect to G2 (family businesses). This may lead us to the conclusion that non-family companies are mostly focused on their business strategies, on innovation management, on electronic commerce, on the home office, and on competitiveness to achieve better financial results.

Table 9. PLS MGA-Bootstrap.

\begin{tabular}{|c|c|c|c|c|c|c|}
\hline Structural Relationship & $\begin{array}{l}\text { Original Path } \\
\text { Coefficient (G1) }\end{array}$ & $\begin{array}{c}\text { Original Path } \\
\text { Coefficient (G2) }\end{array}$ & T Value (G1) & T Value (G2) & $p$ Value (G1) & $p$ Value (G2) \\
\hline (BS) $->(C P)$ & $-0.114^{* *}$ & -0.023 n.s. & 1.640 & 0.399 & 0.050 & 0.345 \\
\hline$(\mathrm{BS})->(\mathrm{EI})$ & -0.167 n.s. & 0.037 n.s. & 0.989 & 0.603 & 0.161 & 0.273 \\
\hline (BS) $->$ (INNM) & -0.004 n.s. & $0.105 * *$ & 0.041 & 1.701 & 0.484 & 0.045 \\
\hline E-commerce -> (CP) & $0.204^{* * *}$ & $0.148^{* * *}$ & 2.881 & 2.865 & 0.002 & 0.002 \\
\hline E-commerce -> (INNM) & $0.324 * * *$ & 0.072 n.s. & 3.934 & 1.269 & 0.000 & 0.102 \\
\hline$(\mathrm{EI})->(\mathrm{CP})$ & $0.189 *$ & $0.081 *$ & 1.517 & 1.565 & 0.065 & 0.059 \\
\hline Home Office -> (CP) & $0.130 * *$ & 0.042 n.s. & 2.182 & 0.749 & 0.015 & 0.227 \\
\hline Home Office -> (INNM) & $0.161 * *$ & $0.124^{* * *}$ & 2.267 & 2.465 & 0.012 & 0.007 \\
\hline (INNM) $->(C P)$ & $0.447 * * *$ & $0.337^{* * *}$ & 6.247 & 5.582 & 0.000 & 0.000 \\
\hline$(\mathrm{INNM})->(\mathrm{EI})$ & 0.026 n.s. & $0.233^{* * *}$ & 0.222 & 4.296 & 0.412 & 0.000 \\
\hline
\end{tabular}

${ }^{* * *} p<0.001 ;{ }^{* *} p<0.01 ;{ }^{*} p<0.05 ;$ n.s.: not significant.

\section{Discussion}

This section discusses the main findings of the research study based on the theory of competitive behavior and the theory based on resources and capabilities. In order to answer the objectives and questions of the investigation, the results derived from the verification of the hypotheses of the proposed theoretical model are described below.

In the first block, we present the results of $\mathrm{H} 1, \mathrm{H} 2$, and $\mathrm{H} 3$. The findings show that business strategies (financial and market) have not been differentiating elements and/or actions to increase the competitiveness of SMEs. The results show that the business strategy does not have significant effects on the management of innovation and the economic indicators of SMEs. Frequently, companies in the time of pandemic have been focusing on other types of actions that allow them to obtain results in a short time and fighting for survival in competitive markets [38,131]. In addition, we observe that business strategy has a small significant but negative effect on corporate performance; therefore, it can be inferred that SMEs are currently adopting innovative strategies such as the use of technology for their market strategies and, in addition, are suffering from a serious financial health problem $[66,67]$. These findings are aligned with the postulates of the theory of com- 
petitive behavior when adopting business strategies to face the external impacts derived from the economic crisis generated by the COVID-19 pandemic [6,11]. On the other hand, the managerial skills and financial capacities of the companies have strong barriers that prevent SMEs from obtaining organizational and financial benefits, which allows us to associate these findings with the theory of business resources and capabilities $[10,49,108]$. The literature on competitive behavior has argued that competitive success leads to the financial profitability of companies. In addition, the RBV shows that companies that execute effective financial and market strategies are mainly able to do so due to the amount of tangible and intangible resources they possess, leading them to a competitive advantage and towards more lasting economic success $[6,132]$. Therefore, the lower the financial capacity of the company, the lower the impact on the adoption of market strategies and innovation practices and economic indicators [68]; these problems affect competitiveness and limit the expansion to other markets [69]. One of the reasons why a significant relationship between financial and market strategies with innovation has not been found may be due to the financial limitation or capacity and the organizational uncertainty of SMEs [70]. The findings reported by Didonet and Díaz-Villavicencio [42] are similar to our results, confirming that the market strategies focused on learning from customers, suppliers, and competitors help detect opportunities and improve innovation management and increase organizational results in SMEs. However, these adversities sometimes encourage SME managers to be more creative and, of course, to promote innovation with greater emphasis [71]. Our findings are in this same direction, highlighting that the risks, organizational uncertainty, and financial insecurity have become more acute in SMEs due to the effects of the COVID-19 pandemic [72]. The efforts of SMEs to maintain financial health and develop innovative marketing strategies have led them to a critical and significant competitive organizational wear, to the point of only surviving and covering operating expenses, which seriously affects financial returns [133,134].

In the second block, the results of $\mathrm{H} 4$ and $\mathrm{H} 5$ are described and present significant and positive effects. These findings allow us to infer that SMEs in this region are in a very strong competitive struggle, and for this, they are generating new ways of working and improving their internal processes to improve innovation management [2,34]. The results allow us to infer that the innovation management has a positive and significant effect on the economic indicators; therefore, the innovation practices that SMEs are generating, in their products, processes, and management, are causing a balanced financial health. Even though in Mexico there are few financial incentives to face the global economic crisis, the organizations called SMEs are supporting this onslaught of the COVID-19 pandemic. In addition, the management of innovation is an elementary factor to continue in the competitive fight because they have managed to maintain a reasonable number of sales and economic benefits that allow them to comply with their obligations [82,84]. These findings are in line with the theory of resources and capabilities, given that those responsible for managing SMEs are applying their creativity and innovation capacities to face market changes, which at present have gone from being physical markets to virtual markets $[10,82,135]$. The study carried out by Lendel et al. [28] highlights the importance of adopting and executing a management model and process for organizational innovation. This requires a high commitment from the employees and managers of the companies, which leads them towards competitive improvement and a more sustainable performance. Our findings are similar to those of the studies by Liu and Yoo [81], which report that intangible resources and strategic direction play a determining role in the innovative performance and financial performance of SMEs. In addition, Caballero-Morales [84] reveals that SMEs in the time of the COVID-19 pandemic were more creative and managed to develop new forms of marketing and improve and adapt products to the needs of consumers, all of which allowed them to remain in the market and obtain acceptable economic results to stabilize their operations. In addition, Lee's [25] studies reveal that ambidextrous innovation (incremental and disruptive) in SMEs is in their daily lives due to current market demands moving towards the digital age. 
In the last block (third), the result of $\mathrm{H} 6$ is described. The findings revealed that the economic impact had a small positive and significant effect on the corporate performance of SMEs in this region. These results allow us to infer that these companies, through the competitive behavior and business capacities of their managers, have managed to maintain a balanced financial health (level of debt, liquidity, and economic solvency), managing to cover operating expenses and costs $[135,136]$. These strategies have allowed the SMEs to invest in innovative actions (improvement in products, processes, and management) to strengthen their marketing processes through new sales channels, such as the use of digital platforms and social networks, actions that have allowed them to keep current customers and reach new customers in order to increase their sales and financial performance $[22,61,87]$. These findings align with competitive behavior theory and resource-based theory. Our findings have a certain degree of similarity with the studies developed by Chiu et al. [88], where it is argued that SMEs in most regions are at financial risk and have high levels of debt, which limits them from obtaining a surplus in their operations. On the other hand, Bongomin [86] showed that SMEs in underdeveloped regions develop unsound financial strategies, and there is a poor culture of financial health, which leads them to achieve unprofitable and sustainable economic indicators.

In addition to the main hypotheses of the model, two control variables were analyzed in order to strengthen the investigation. The findings revealed that e-commerce has been an innovative strategy for SMEs in this region to improve their innovation practices and corporate performance. Recent studies have shown that during COVID-19, SMEs adopted and applied technological innovation through the improvement of their marketing and sales processes through digital platforms and social networks [25,137]. On the other hand, as part of the innovative strategies that SMEs are implementing, the home office is an action that is allowing adaptation to new ways of working. These activities and strategic actions are leading companies to improve their innovation management processes and above all to face current global challenges $[138,139]$.

The COVID-19 crisis may forever change the way we do business and may mark a quantum leap in work-life balance. This is true not only in the context of the established companies but also for entrepreneurs [140]. Many of the most challenging problems could benefit from the solutions of others in different parts of the world [23]; this is the power of the convergence of technologies, people, and organizations that work together for a purpose [25]. The convergence of ideas from different entities provides new energy for innovation. Previously unlikely partnerships are just one example of society coming together to face a common adversary [140] and companies have already realized that they should not work alone; so, everyone has already established alliances, collaborations or alliances with others [141]. Remote innovators rely on different types of information, i.e., technological or scientific information that is less time-sensitive than market-related information [142].

Therefore, the adoption of dynamic open innovation practices represents an organizational and financial challenge for companies [13]. Big data about society and markets will provide a new combination of technology and markets that crosses the boundaries of companies [20]. Remote work and telecommuting can motivate open innovation and the construction of new business models by introducing new information about markets and society. Companies can accurately combine customer input while allowing them to be more closely involved in the design process and product-cycle management [143].

Finally, in this section we have also considered it very important to discuss the results of the multigroup analysis included in the study. For this purpose, the categorical variable (family businesses and non-family businesses) was included, to verify its effects in the proposed theoretical model. The results have revealed that the managers of non-family businesses are the ones who have paid the greatest attention to the implementation of innovative strategies to minimize the effects of the global economic crisis [144]. The literature on efficiency in strategic decision making and risk taking in family business and non-family business SMEs has divergent conclusions [145]. It is important to state that the results 
of the multigroup analysis shed light that showed that family businesses and non-family businesses have suffered the blows of the COVID-19 pandemic. We can see this in the non-significant results of financial strategies and the financial strategies of the market innovation and corporate performance of the SMEs analyzed. In this study, we have considered two substantial strategic actions as part of open innovation (e-commerce and home office). The study on open innovation strategies in family business and non-family business SMEs is completely divergent [146]. Some views maintain that non-family businesses invest more resources and develop a greater capacity for innovation than family businesses [146,147]. Therefore, non-family businesses have a greater propensity and ease towards open innovation, which makes them look like companies that are more collaborative with the outside world and more open to capturing knowledge. These actions allow these types of companies to raise their innovative practices that impact financial performance [148]. These postulates are related to our findings from the multigroup analysis.

\section{Conclusions}

This section summarizes the findings of the study through a series of theoretical and practical conclusions and implications.

First, it is concluded that the financial strategies and markets that SMEs are currently implementing are not actions that generate competitive advantage; improvements for the management of innovation are much less a determining factor in raising corporate performance. Therefore, this first conclusion provides an important contribution to the development of competitive behavior theory and resource-based theory. Deriving from these results, the study shows the following practical implications for the improvement of SME management: (1) it is recommended that companies migrate from the traditional business model to business models based on innovation [2], and (2) it is recommended to focus the resources and capabilities in maintaining financial health and to invest in digital platforms for the commercialization and sale of goods and services $[149,150]$.

Secondly, the results of the second block allow us to corroborate that the innovation management of SMEs during the COVID-19 pandemic has been decisive for their survival. These findings strengthen and strongly contribute to the development of the theory of resources and capabilities. Despite the fact that innovation management has significant effects on maintaining economic indicators and corporate performance, these results have allowed the following practical implications to be issued for the improvement of SME management: (1) it is important to invest in and adopt technology to automate production processes and commercialization processes $[54,151]$; (2) it is recommended to adopt new business models for commercialization and online sales through digital platforms, to improve e-commerce transactions [152,153]; and (3) strengthen alliances with other companies and with universities, research centers, and governments to improve the efficiency of innovation management $[154,155]$.

The third block of the study has shown that the economic indicators presented by the SME have remained stable and have allowed a moderate influence on the results of the corporate performance. However, in the face of the COVID-19 situation, the challenges and the obstacles are strong for SMEs; so, it is important to question whether they will be able to continue withstanding the waves of the great tide called the global economic crisis. For this reason, the following practical implications are issued: (1) be financed through different methods, such as subsidies from government institutions, crowdlending, crowd factoring, and crowdfunding [88,156], and (2) SME managers are recommended to solidify their strategic plans (administrative, operational, and financial) [2,106].

The research provides an important contribution to the literature on competitive organizational behavior through the resources and capabilities deployed by SMEs. The originality and novelty of the study is reflected in analyzing the current state of SMEs in a country with an emerging and/or developing economy. The scarcity of this type of study in SMEs in this region highlights the relevance of strategic behavior analysis and innovation management as factors that trigger competitiveness and corporate performance [151]. The 
literature that analyzes competitive organizational behavior through resources and business capabilities emphasizes the importance of financial resources and market strategies as key strategies to trigger innovation and raise financial performance. Our determinations inform us that a lower financial capacity and inefficient market strategy do not have significant effects on innovation and corporate performance. These results are consistent with the studies carried out by González-Velasco [134] and Bodlaj et al. [68] on financial restrictions and their effects on the performance of SMEs. The research carried out by Ullah et al. [157] reports that financial strategies reinforce the postulates of the RBV theory, explaining that these actions are intangible resources that provide a higher value in the innovation and corporate performance of SMEs. In the context of our research, these results are in another direction. On the other hand, our study shows an important contribution to the literature on open innovation. The RBV has stated that SMEs are less inclined towards open innovation practices. However, it is important to note that SMEs that have fewer resources and entrepreneurial capabilities tend to be more creative and innovative. Our findings have confirmed this, with new marketing practices through technology being a key element in triggering innovation and corporate performance. Moreover, this is on the right path towards maximizing resources through the home office. These findings are similar and consistent with studies developed by [21,122,158]. In this same direction, the study carried out by Nofiani et al. [159] shows that SMEs are currently in a state plagued by uncertainty and must adapt to market situations and internal needs. To this end, they develop multiple balanced and combined ambidextrous strategies focused on innovation to sustain appropriate financial performance and survive in highly competitive markets [160,161]. The strategies of anticipation, adaptation to change, and cooperation (open innovation) to acquire external resources are adopted more frequently by the managers of SMEs in periods of economic recession [29].

Finally, given that many investigations have limitations, in this section we describe some of the limitations that came up during the investigation. The first limitation is the sample explored in the study because it is from a single specific region; therefore, in the future, it is important to consider a sample from different regions and even from other countries to develop comparative analyses. The second limitation is the responses obtained in the study because they are the subjective opinions of the managers of the companies. In Mexico, it is very difficult to obtain hard data on the innovation and economic indicators of companies. Regarding the third and last limitation, we consider that in the future the SEM technique can be used, based on covariance. On the other hand, the main future lines that are revealed are to continue analyzing the behavior of the SME and complete the proposed model. We recommend incorporating constructs that allow evaluating and verifying the effect of open innovation and business resilience, to see their behavior and financial performance in SMEs. COVID-19 has enhanced the collaborative mindset of SMEs, driven by a 'shared cause' that revolves around urgency. This collaborative mentality does not seem to be temporary; it is likely that most SMEs will continue like this after the crisis as they have already understood the benefits of collaboration, and this will drive further the development of open innovation.

Author Contributions: L.E.V.-J. is the author of the manuscript and the general manager of the research project, manager of the research resources, and responsible for preparing the methodology, results, and conclusions of the study. M.C.-V. collaborated with the general review of the document and with the construction of the hypotheses from the empirical and theoretical context of the model. E.A.R.-E. collaborated with the review of the writing of the document and the review of the introduction of the manuscript. All authors have read and agreed to the published version of the manuscript.

Funding: This paper received funding for its development and publication from the PROFAPI Program (ITSON Institutional Strengthening Research Program) (2021_073). 
Institutional Review Board Statement: The study was conducted according to the guidelines of the Declaration of Helsinki and approved by the Institutional Review Board (or Ethics Committee) of Instituto Tecnológico de Sonora (PROFAPI 2021_0073).

Informed Consent Statement: Informed consent was obtained from all subjects involved in the study.

Data Availability Statement: The data and the questionnaire used in the study are available to other authors who require access to this material.

Conflicts of Interest: The author declares no potential conflicts of interest with respect to the research, authorship, and publication of this article.

\section{Appendix A}

\begin{tabular}{|c|c|c|}
\hline Construct/Indicator & Ítems & Factor Loading \\
\hline \multicolumn{3}{|l|}{ Business Strategy (BS) } \\
\hline \multicolumn{3}{|l|}{ Financial Strategy } \\
\hline BSF1 & We have canceled planned investments & $0.847^{* * *}$ \\
\hline BSF2 & We have a specific risk management plan & $0.815^{* * *}$ \\
\hline BSF3 & We have adopted strategies to manage the liquidity of the company & $0.754 * * *$ \\
\hline \multicolumn{3}{|l|}{ Market Strategy } \\
\hline BSM1 & We have modified the offer of products/services to approach new clients & $0.787 * * *$ \\
\hline BSM2 & We have had to lower the prices of products/services & $0.811^{* * *}$ \\
\hline $\mathrm{BSM} 3$ & We have adopted digital advertising strategies & $0.874^{* * *}$ \\
\hline \multicolumn{3}{|c|}{ Innovation Management (INNM) } \\
\hline \multicolumn{3}{|c|}{ Product Innovation } \\
\hline PRODINN1 & We have made changes or improvements to our products/services & $0.907 * * *$ \\
\hline PRODINN2 & We have launched new products/services on the market & $0.890 * * *$ \\
\hline \multicolumn{3}{|l|}{ Process Innovation } \\
\hline PROCINN1 & We have made changes or improvements in the production processes & $0.881 * * *$ \\
\hline PROCINN2 & We have purchased new supplies and equipment & $0.859 * * *$ \\
\hline \multicolumn{3}{|l|}{ Organizational innovation } \\
\hline ORGINN1 & We have made new changes or improvements in the organization & $0.905^{* * *}$ \\
\hline ORGINN2 & We have made new changes or improvements in purchases and/or supplies & $0.911 * * *$ \\
\hline ORGINN3 & We have made new changes or improvements in the commercial and/or sales process & $0.903 * * *$ \\
\hline \multicolumn{3}{|l|}{ Economic Impact (EI) } \\
\hline EI1 & It has suffered impacts at the billing level & $0.686 * * *$ \\
\hline EI2 & Has suffered impacts on profitability & $0.788 * * *$ \\
\hline $\mathrm{EI} 3$ & Has suffered impacts on productivity & $0.823^{* * *}$ \\
\hline EI4 & It has suffered impacts in the realization of investments & $0.784 * * *$ \\
\hline EI5 & It has suffered impacts on the level of debt & $0.684^{* * *}$ \\
\hline EI6 & It has suffered impacts on the level of liquidity & $0.820 * * *$ \\
\hline \multicolumn{3}{|c|}{ Corporate Performance $(\mathrm{CP})$} \\
\hline \multicolumn{3}{|c|}{ Financial Performance } \\
\hline FP1 & Customer satisfaction & $0.806^{* * *}$ \\
\hline FP2 & Speed of adaptation to changes in the market & $0.854 * * *$ \\
\hline FP3 & Speed of sales growth & $0.849 * * *$ \\
\hline FP4 & Increased profitability & $0.799 * * *$ \\
\hline \multicolumn{3}{|l|}{ Non-financial performance } \\
\hline FNP1 & Efficiency of production processes & $0.868 * * *$ \\
\hline FNP2 & Employee satisfaction & $0.897 * * *$ \\
\hline FNP3 & Degree of work absenteeism & $0.807^{* * *}$ \\
\hline
\end{tabular}

*** $p<0.001=99 \%$ significance.

\section{References}

1. Nelson, R.R. Economic development from the perspective of evolutionary economic theory. Oxford Dev. Stud. 2007, 36, 9-21. [CrossRef]

2. Teece, D.J. Business models, business strategy and innovation. Long Range Plann. 2010, 43, 172-194. [CrossRef]

3. World Bank World Bank Group COVID-19 Crisis Response. Available online: https://www.worldbank.org/en/news/ infographic/2020/11/17/world-bank-group-COVID-19-crisis-response (accessed on 22 October 2021).

4. Organization for Economic Cooperation and Development. COVID-19 in Latin America and the Caribbean: Socio-Economic Consequences and Policy Priorities; OECD Publishing: Paris, France, 2020. 
5. Balcazar, F.E.; Shupert, M.K.; Daniels, A.C.; Mawhinney, T.C.; Hopkins, B.L. An Objective Review and Analysis of Ten Years of Publication in the Journal of Organizational Behavior Management. J. Organ. Behav. Manag. 1989, 10, 7-37. [CrossRef]

6. Barney, J.B.; Zajac, E.J. Competitive Organizational Behavior: Toward an Organizationally-Based Theory of Competitive Advantage. Strateg. Manag. J. 1994, 15, 5-9. [CrossRef]

7. Han, J.K.; Kim, N.; Srivastava, R.K. Market Orientation and Organizational Performance: Is Innovation a Missing Link? J. Mark. 1998, 62, 30. [CrossRef]

8. Slater, S.F.; Narver, J.C. Market Orientation and the Learning Organization. J. Mark. 1995, 59, 63-74. [CrossRef]

9. Matsuno, K.; Mentzer, J.T. Market Orientation: Reconciliation of Two Conceptualizations; Springer: Cham, Switzerland, 2015; pp. 49-55. [CrossRef]

10. Barney, J.B.; Ketchen, D.J.; Wright, M. The future of resource-based theory: Revitalization or decline? J. Manag. 2011, 37, 1299-1315. [CrossRef]

11. Barney, J.; Wright, M.; Ketchen, D.J. The resource-based view of the firm: Ten years after 1991. J. Manag. 2001, 27, 625-641. [CrossRef]

12. Hilmersson, F.P.; Hilmersson, M. Networking to accelerate the pace of SME innovations. J. Innov. Knowl. 2021, 6, 43-49. [CrossRef]

13. Valdez-Juárez, L.E.; Gallardo-Vázquez, D.; Ramos-Escobar, E.A. Online buyers and open innovation: Security, experience, and satisfaction. J. Open Innov. Technol. Mark. Complex. 2021, 7, 37. [CrossRef]

14. Chesbrough, H. The era of open innovation. Manag. Innov. Chang. 2003, 127, 35-41.

15. Wei, N.; Li, Z.W. Telepresence and interactivity in mobile learning system: Its relation with open innovation. J. Open Innov. Technol. Mark. Complex. 2021, 7, 78. [CrossRef]

16. Adamides, E.; Karacapilidis, N. Information technology for supporting the development and maintenance of open innovation capabilities. J. Innov. Knowl. 2020, 5, 29-38. [CrossRef]

17. Liu, Q.; Yang, Z.; Cai, X.; Du, Q.; Fan, W. The more, the better? The effect of feedback and user's past successes on idea implementation in open innovation communities. J. Assoc. Inf. Sci. Technol. 2021, 73, 376-392. [CrossRef]

18. Yun, J.J.; Zhao, X.; Park, K. Sustainability Condition of Open Innovation: Dynamic Growth of Alibaba from SME to Large. Enterprise 2020, 12, 4379. [CrossRef]

19. Saura, J.R.; Palacios-Marqués, D.; Ribeiro-Soriano, D. Exploring the boundaries of open innovation: Evidence from social media mining. Technovation 2022, 102447. [CrossRef]

20. Yun, J.J.; Kim, D.; Yan, M.R. Open innovation engineering-Preliminary study on new entrance of technology to market. Electronics 2020, 9, 791. [CrossRef]

21. Konrad-Märk, M. Remote innovation: How remote work relates to open Innovation. In Proceedings of the The ISPIM Innovation Conference-Innovating Our Common Future, Manchester, UK, 20-23 June 2021; pp. 1-21.

22. Adam, N.A.; Alarifi, G. Innovation practices for survival of small and medium enterprises (SMEs) in the COVID-19 times: The role of external support. J. Innov. Entrep. 2021, 10, 15. [CrossRef]

23. Chesbrough, H. To recover faster from COVID-19, open up: Managerial implications from an open innovation perspective. Ind. Mark. Manag. 2020, 88, 410-413. [CrossRef]

24. Valdez-Juárez, E.L.; Castillo-Vergara, M. Technological Capabilities, Open Innovation, and Eco-Innovation: Dynamic Capabilities to Increase Corporate Performance of SMEs. J. Open Innov. Technol. Mark. Complex. 2021, 7, 8. [CrossRef]

25. Lee, S.M.; Trimi, S. Convergence innovation in the digital age and in the COVID-19 pandemic crisis. J. Bus. Res. 2021, 123, 14-22. [CrossRef] [PubMed]

26. Čiarnienè, R.; Stankevičiūtè, G. Theoretical Framework of E-Business Competitiveness. Procedia-Soc. Behav. Sci. 2015, 213, 734-739. [CrossRef]

27. Barney, J. The Resource-Based Theory of the Firm. Organ. Sci. 1996, 7, 469. [CrossRef]

28. Weerawardena, J.; Mavondo, F.T. Capabilities, innovation and competitive advantage. Ind. Mark. Manag. 2011, 40, 1220-1223. [CrossRef]

29. Lendel, V.; Hittmár, Š.; Siantová, E. Management of Innovation Processes in Company. Procedia Econ. Financ. 2015, 23, 861-866. [CrossRef]

30. Valdez-Juárez, L.; Solano-Rodríguez, O.J.; Philippe-Martin, D. Modes of learning and profitability in Colombian and Mexican SMEs. J. High Technol. Manag. Res. 2018, 29, 193-203. [CrossRef]

31. Alcalde-Heras, H.; Iturrioz-Landart, C.; Aragon-Amonarriz, C. SME ambidexterity during economic recessions: The role of managerial external capabilities. Manag. Decis. 2019, 57, 21-40. [CrossRef]

32. Povolná, L. Innovation strategy in Small and Medium Sized Enterprises (SMEs) in the context of growth and recession indicators J. Open Innov. Technol. Mark. Complex. 2019, 5, 32. [CrossRef]

33. Ritter, T.; Gemünden, H.G. The impact of a company's business strategy on its technological competence, network competence and innovation success. J. Bus. Res. 2004, 57, 548-556. [CrossRef]

34. Bouncken, R.B.; Pesch, R.; Kraus, S. SME innovativeness in buyer-seller alliances: Effects of entry timing strategies and interorganizational learning. Rev. Manag. Sci. 2015, 9, 361-384. [CrossRef]

35. Bentley-Goode, K.A.; Newton, N.J.; Thompson, A. Business Strategy and Internal Control Over Financial Reporting. Audit. A J. Pract. Theory 2017, 36, 49-69. [CrossRef] 
36. Jardon, C.M.; Martinez-Cobas, X. Trust and opportunism in the competitiveness of small-scale timber businesses based on innovation and marketing capabilities. Bus. Strateg. Dev. 2021, 1-11. [CrossRef]

37. Hahn, K. Innovation in times of financialization: Do future-oriented innovation strategies suffer? Examples from German industry. Res. Policy 2019, 48, 923-935. [CrossRef]

38. Tell, J. Managerial strategies in small, fast-growing manufacturing firms. J. Manag. Dev. 2012, 31, 700-710. [CrossRef]

39. Zhou, X.; Du, J. Does environmental regulation induce improved financial development for green technological innovation in China? J. Environ. Manag. 2021, 300, 113685. [CrossRef] [PubMed]

40. Cao, Z.; Chen, S.X.; Lee, E. Does business strategy influence interfirm financing? Evidence from trade credit. J. Bus. Res. 2022, 141, 495-511. [CrossRef]

41. Song, L.; Jing, L. Strategic orientation and performance of new ventures: Empirical studies based on entrepreneurial activities in China. Int. Entrep. Manag. J. 2017, 13, 989-1012. [CrossRef]

42. Ngo, L.V.; O'Cass, A. In search of innovation and customer-related performance superiority: The role of market orientation, marketing capability, and innovation capability interactions. J. Prod. Innov. Manag. 2012, 29, 861-877. [CrossRef]

43. Donkor, J.; Donkor, G.N.A.; Kankam-Kwarteng, C.; Aidoo, E. Innovative capability, strategic goals and financial performance of SMEs in Ghana. Asia Pacific J. Innov. Entrep. 2018, 12, 238-254. [CrossRef]

44. Didonet, S.; Diaz-Villavicencio, G. Innovation management in market-oriented SMEs: Learning and internal arrangements for innovation. Int. J. Organ. Anal. 2020, 28, 985-1003. [CrossRef]

45. Porter, M.E. Towards a dynamic theory of strategy. Strateg. Manag. J. 1991, 12, 95-117. [CrossRef]

46. Vorhies, D.W.; Morgan, R.E.; Autry, C.W. Product-market strategy and the marketing capabilities of the firm: Impact on market effectiveness and cash flow performance. Strateg. Manag. J. 2009, 30, 1310-1334. [CrossRef]

47. Penrose, E. The Theory of the Growth of the Firm Blackwell; Oxford University Press: London, UK, 1959.

48. Agustia, D.; Muhammad, N.P.A.; Permatasari, Y. Earnings management, business strategy, and bankruptcy risk: Evidence from Indonesia. Heliyon 2020, 6, e03317. [CrossRef]

49. González-Rodríguez, M.R.; Jiménez-Caballero, J.L.; Martín-Samper, R.C.; Köseoglu, M.A.; Okumus, F. Revisiting the link between business strategy and performance: Evidence from hotels. Int. J. Hosp. Manag. 2018, 72, 21-31. [CrossRef]

50. McPhee, W. A new sustainability model. J. Bus. Strategy 2014, 35, 4-12. [CrossRef]

51. Umadia Sr., K.; Kasztelnik, K. The Financial Innovative Business Strategies of Small to Medium Scale Enterprises in Developing Country and Influence for the Global Economy Performance. Socioecon. Challenges 2020, 4, 1. [CrossRef]

52. Stead, J.G.; Stead, W.E. Spiritual capabilities: Keys to successful sustainable strategic management. In Spirituality and Sustainability; Springer: Berlin/Heidelberg, Germany, 2016; pp. 89-103.

53. Dodd, M.D. Intangible resource management: Social capital theory development for public relations. J. Commun. Manag. 2016, 20, 289-311. [CrossRef]

54. Backman, C.A.; Verbeke, A.; Schulz, R.A. The drivers of corporate climate change strategies and public policy: A new resourcebased view perspective. Bus. Soc. 2017, 56, 545-575. [CrossRef]

55. Akter, S.; Wamba, S.F.; Gunasekaran, A.; Dubey, R.; Childe, S.J. How to improve firm performance using big data analytics capability and business strategy alignment? Int. J. Prod. Econ. 2016, 182, 113-131. [CrossRef]

56. Park, W.; Sung, C.S.; Byun, C.G. Impact of unlisted small and medium-sized enterprises' business strategies on future performance and growth sustainability. J. Open Innov. Technol. Mark. Complex. 2019, 5, 60. [CrossRef]

57. Nurhayati, I.; Endri, E.; Aminda, R.S.; Muniroh, L. Impact of COVID-19 on performance evaluation large market capitalization stocks and open innovation. J. Open Innov. Technol. Mark. Complex. 2021, 7, 56. [CrossRef]

58. Habib, A.; Hasan, M.M. Business strategy, overvalued equities, and stock price crash risk. Res. Int. Bus. Financ. 2017, 39, 389-405. [CrossRef]

59. Houqe, M.N.; Kerr, R.; Monem, R. Business Strategy, Economic Growth, and Earnings Quality (Working Paper); Victoria University of Wellington: Wellington, New Zealand, 2015.

60. Bentley, K.A.; Omer, T.C.; Sharp, N.Y. Business strategy, financial reporting irregularities, and audit effort. Contemp. Account. Res. 2013, 30, 780-817. [CrossRef]

61. Yost, E.; Kizildag, M.; Ridderstaat, J. Financial recovery strategies for restaurants during COVID-19: Evidence from the US restaurant industry. J. Hosp. Tour. Manag. 2021, 47, 408-412. [CrossRef]

62. Campbell-Hunt, C. What have we learned about generic competitive strategy? A meta-analysis. Strateg. Manag. J. 2000, 21, 127-154. [CrossRef]

63. Lacerda, R.T.d.O.; Ensslin, L.; Ensslin, S.R. Uma análise bibliométrica da literatura sobre estratégia e avaliação de desempenho. Gestão Produção 2012, 19, 59-78. [CrossRef]

64. Bryan, D.; Fernando, G.D.; Tripathy, A. Bankruptcy risk, productivity and firm strategy. Rev. Account. Financ. 2013, 12, 309-326. [CrossRef]

65. Naidoo, V. Firm survival through a crisis: The influence of market orientation, marketing innovation and business strategy. Ind. Mark. Manag. 2010, 39, 1311-1320. [CrossRef]

66. Ittner, C.D.; Larcker, D.F.; Rajan, M.V. The choice of performance measures in annual bonus contracts. Account. Rev. 1997, 72, 231-255. 
67. Acquaah, M. Management control systems, business strategy and performance: A comparative analysis of family and non-family businesses in a transition economy in sub-Saharan Africa. J. Fam. Bus. Strateg. 2013, 4, 131-146. [CrossRef]

68. Belitski, M.; Guenther, C.; Kritikos, A.S.; Thurik, R. Economic effects of the COVID-19 pandemic on entrepreneurship and small businesses. Small Bus. Econ. 2021, 58, 593-609. [CrossRef]

69. Dörr, J.O.; Licht, G.; Murmann, S. Small firms and the COVID-19 insolvency gap. Small Bus. Econ. 2021, 58, 593-609. [CrossRef]

70. Bodlaj, M.; Kadic-Maglajlic, S.; Vida, I. Disentangling the impact of different innovation types, financial constraints and geographic diversification on SMEs' export growth. J. Bus. Res. 2020, 108, 466-475. [CrossRef]

71. Felzensztein, C.; Saridakis, G.; Idris, B.; Elizondo, G.P. Do economic freedom, business experience, and firm size affect internationalization speed? Evidence from small firms in Chile, Colombia, and Peru. J. Int. Entrep. 2021, 1-42. [CrossRef]

72. Hewitt-Dundas, N. Resource and Capability Constraints to Innovation in Small and Large Plants. Small Bus. Econ. 2006, 26, 257-277. [CrossRef]

73. Scopelliti, I.; Cillo, P.; Busacca, B.; Mazursky, D. How Do Financial Constraints Affect Creativity? J. Prod. Innov. Manag. 2014, 31, 880-893. [CrossRef]

74. Grözinger, A.C.; Wolff, S.; Ruf, P.J.; Moog, P. The power of shared positivity: Organizational psychological capital and firm performance during exogenous crises. Small Bus. Econ. 2021, 58, 689-716. [CrossRef]

75. Gyedu, S.; Heng, T.; Ntarmah, A.H.; He, Y.; Frimppong, E. The impact of innovation on economic growth among G7 and BRICS countries: A GMM style panel vector autoregressive approach. Technol. Forecast. Soc. Chang. 2021, 173, 121169. [CrossRef]

76. Rogo, H.B.; Shariff, M.N.M.; Hafeez, M.H. Moderating Effect of Access to Finance on the Relationship between Total Quality Management, Market Orientation and Small and Medium Enterprises Performance: A Proposed Framework. Int. Rev. Manag. Mark. 2017, 1, 119-127.

77. Keupp, M.M.; Palmié, M.; Gassmann, O. The Strategic Management of Innovation: A Systematic Review and Paths for Future Research. Int. J. Manag. Rev. 2012, 14, 367-390. [CrossRef]

78. Expósito, A.; Sanchis-Llopis, J.A. The relationship between types of innovation and SMEs' performance: A multi-dimensional empirical assessment. Eurasian Bus. Rev. 2019, 9, 115-135. [CrossRef]

79. Fabrizio, C.M.; Kaczam, F.; de Moura, G.L.; da Silva, L.S.C.V.; da Silva, W.V.; da Veiga, C.P. Competitive Advantage and Dynamic Capability in Small and Medium-Sized Enterprises: A Systematic Literature Review and Future Research Directions; Springer: Berlin/Heidelberg, Germany, 2021; ISBN 0123456789.

80. Liem, N.T.; Khuong, N.V.; Khanh, T.H.T. Firm constraints on the link between proactive innovation, open innovation and firm performance. J. Open Innov. Technol. Mark. Complex. 2019, 5, 88. [CrossRef]

81. Na, K.; Kang, Y.H. Relations between innovation and firm performance of manufacturing firms in Southeast Asian emerging markets: Empirical evidence from Indonesia, Malaysia, and Vietnam. J. Open Innov. Technol. Mark. Complex. 2019, 5, 98. [CrossRef]

82. Lu, Y.; Wu, J.; Peng, J.; Lu, L. The perceived impact of the COVID-19 epidemic: Evidence from a sample of 4807 SMEs in Sichuan Province, China. Environ. Hazards 2020, 19, 323-340. [CrossRef]

83. Liu, Y.; Kim, J.; Yoo, J. Intangible resources and internationalization for the innovation performance of Chinese high-tech firms. J. Open Innov. Technol. Mark. Complex. 2019, 5, 52. [CrossRef]

84. Cainelli, G.; Evangelista, R.; Savona, M. The impact of innovation on economic performance in services. Serv. Ind. J. 2004, 24, 116-130. [CrossRef]

85. Gerguri, S.; Ramadani, V. The Impact of Innovation into the Economic Growth. Munich Pers. RePEc Arch. Pap. 2010, 23, 1-22.

86. Caballero-Morales, S.O. Innovation as recovery strategy for SMEs in emerging economies during the COVID-19 pandemic. Res. Int. Bus. Financ. 2021, 57, 101396. [CrossRef]

87. Gherghina, S.C.; Botezatu, M.A.; Hosszu, A.; Simionescu, L.N. Small and medium-sized enterprises (SMEs): The engine of economic growth through investments and innovation. Sustainability 2020, 12, 347. [CrossRef]

88. Okello, C.B.; Mpeera Ntayi, J.; Munene, J.C.; Malinga, A.C. The relationship between access to finance and growth of SMEs in developing economies: Financial literacy as a moderator. Rev. Int. Bus. Strateg. 2017, 27, 520-538. [CrossRef]

89. World Bank. Doing business 2014: Understanding Regulations for Small and Medium-Size Enterprises; World Bank Publications: Washington, DC, USA, 2013; Volume 11, ISBN 0821399845.

90. Chiu, I.H.Y.; Kokkinis, A.; Miglionico, A. Addressing the challenges of post-pandemic debt management in the consumer and SME sectors: A proposal for the roles of UK financial regulators. J. Bank. Regul. 2021, 1-19. [CrossRef]

91. Chin, W.W. The partial least squares approach to structural equation modeling. In Modern Methods for Business Research; Marcoulides, G.A., Ed.; Lawrence Erlbaum Associates Publishers: London, UK, 1998; pp. 295-336.

92. Barroso, C.; Carrión, G.C.; Roldán, J.L. Applying Maximum Likelihood and PLS on Different Sample Sizes: Studies on SERVQUAL Model and Employee Behavior Model. In Handbook of Partial Least Squares; Springer: Berlin/Heidelberg, Germany, 2010; pp. 427-447.

93. Benitez, J.; Henseler, J.; Castillo, A.; Schuberth, F. How to perform and report an impactful analysis using partial least squares: Guidelines for confirmatory and explanatory IS research. Inf. Manag. 2020, 57, 103168. [CrossRef]

94. INEGI. Instituto Nacional de Geografía, Estadística e Informática. Censos Económicos 2019; INEGI: Mexico City, Mexico, 2019.

95. Reio, T.G. The Threat of Common Method Variance Bias to Theory Building. Hum. Resour. Dev. Rev. 2010, 9, 405-411. [CrossRef]

96. Podsakoff, P.M.; MacKenzie, S.B.; Lee, J.; Podsakoff, N.P. Common Method Bias in Behavioral Research: A Critical Review of the Literature and recommended remedies. J. Appl. Psychol. 2003, 88, 5. [CrossRef] [PubMed] 
97. Gorrell, G.; Ford, N.; Madden, A.; Holdridge, P.; Eaglestone, B. Countering method bias in questionnaire-based user studies. J. Doc. 2011, 67, 507-524. [CrossRef]

98. Hair, J.F.; Risher, J.J.; Sarstedt, M.; Ringle, C.M. When to use and how to report the results of PLS-SEM. Eur. Bus. Rev. 2019, 31, 2-24. [CrossRef]

99. Henseler, J. Bridging Design and Behavioral Research with Variance-Based Structural Equation Modeling. J. Advert. 2017, 46, 178-192. [CrossRef]

100. Wright, R.; Campbell, D.; Thatcher, J.; Roberts, N. Operationalizing Multidimensional Constructs in Structural Equation Modeling: Recommendations for IS Research. Commun. Assoc. Inf. Syst. 2012, 30, 368-412. [CrossRef]

101. Vogus, T.J.; Sutcliffe, K.M. Organizational resilience: Towards a theory and research agenda. Conf. Proc. IEEE Int. Conf. Syst. Man Cybern. 2007, 3418-3422. [CrossRef]

102. Zighan, S.; Ruel, S. SMEs' resilience from continuous improvement lenses. J. Entrep. Emerg. Econ. 2021. [CrossRef]

103. Johnson, J.S.; Sohi, R.S. Getting business-to-business salespeople to implement strategies associated with introducing new products and services. Ind. Mark. Manag. 2017, 100, 137-149. [CrossRef]

104. Calandro, J.; Flynn, R. On financial strategy. Bus. Strateg. Ser. 2007, 8, 409-417. [CrossRef]

105. Mohammadi, P.; Fathi, S.; Kazemi, A. Differentiation and financial performance: A meta-analysis. Compet. Rev. 2019, $29,573-591$. [CrossRef]

106. Chaudhary, A.K. Impact of behavioral finance in investment decisions and strategies-a fresh approach. Mar. Biodivers. 2016, 2, 85-92. [CrossRef]

107. OECD. Organisation for Economic Co-operation and Development. Statistical Office of the European Communities. Oslo Manual: Guidelines for Collecting and Interpreting Technological Innovation Data; Organisation for Economic Co-operation and Development: Paris, France, 2005; ISBN 9264013105.

108. Teece, D.J. Dynamic Capabilities and Strategic Management: Organizing for Innovation and Growth; Oxford University Press: New York, NY, USA, 2009; ISBN 978-0-19-969190-6.

109. Frishammar, J.; Richtnér, A.; Brattström, A.; Magnusson, M.; Björk, J. Opportunities and challenges in the new innovation landscape: Implications for innovation auditing and innovation management. Eur. Manag. J. 2019, 37, 151-164. [CrossRef]

110. Parida, V.; Sjödin, D.R.; Wincent, J.; Kohtamäki, M. Mastering the transition to product-service provision: Insights into business models, Learning activities, and capabilities. Res. Technol. Manag. 2014, 57, 44-52. [CrossRef]

111. OECD. Organisation for Economic Co-operation and Development. Small, Medium, Strong. Trends in SME Performance and Business Conditions; OECD Publishing: Paris, France, 2017; ISBN 9264275673.

112. Geyskens, I.; Gielens, K.; Dekimpe, M.G. The Market Valuation of Internet Channel Additions. J. Mark. 2002, 66, 102-119. [CrossRef]

113. Kalyanaram, G.; Robinson, W.T.; Urban, G.L. Order of Market Entry: Established Empirical Generalizations, Emerging Empirical Generalizations, and Future Research. Mark. Sci. 1995, 14, G212-G221. [CrossRef]

114. Quinn, J.B. The Strategic Process. Concept, Context, Cases; New York Irwin: New York, NY, USA, 1991.

115. Aras, G.; Aybars, A.; Kutlu, O. Managing corporate performance. Int. J. Product. Perform. Manag. 2010, 59, 229-254. [CrossRef]

116. Roldán, J.L.; Cepeda, G. Modelos de Ecuaciones Estructurales basados en la Varianza: Partial Least Squares (PLS) para Investigadores en Ciencias Sociales. Univ. Sevilla Sevilla Spain 2016, 34, 589-597.

117. Braun, I.; Hess, R.; Schill, A.-I.W.C. Teleworking support for small and medium-sized enterprises. IFIP World Comput. Congr. 1998, 98, 1-13.

118. Wong, A.H.K.; Cheung, J.O.; Chen, Z. Promoting effectiveness of "working from home": Findings from Hong Kong working population under COVID-19. Asian Educ. Dev. Stud. 2021, 10, 210-228. [CrossRef]

119. Raišienè, A.G.; Rapuano, V.; Varkulevičiūtè, K. Sensitive men and hardy women: How do millennials, xennials and gen x manage to work from home? J. Open Innov. Technol. Mark. Complex. 2021, 7, 106. [CrossRef]

120. Berchicci, L.; Freel, M.; De Jong, J.P.J. Remote collaboration, absorptive capacity, and the innovative output of high-tech small firms. Dan. Res. Unit Ind. Dyn. 2013, 13, 1-28.

121. Loia, F.; Adinolfi, P. Teleworking as an eco-innovation for sustainable development: Assessing collective perceptions during COVID-19. Sustainability 2021, 13, 4823. [CrossRef]

122. Manual for the Production of Statistics on the Digital Economy 2020; UNCTAD (United Nations Conference on Trade and Development): New York, NY, USA, 2021.

123. Guercini, S.; Ranfagni, S.; Runfola, A. E-commerce internationalization for top luxury fashion brands: Some emerging strategic issues. J. Manag. Dev. 2020, 39, 423-436. [CrossRef]

124. Farmania, A.; Elsyah, R.D.; Tuori, M.A. Transformation of crm activities into e-crm: The generating e-loyalty and open innovation. J. Open Innov. Technol. Mark. Complex. 2021, 7, 109. [CrossRef]

125. Ho-Dac, N.N. The value of online user generated content in product development. J. Bus. Res. 2020, 112, 136-146. [CrossRef]

126. Henseler, J.; Ringle, C.M.; Sarstedt, M. A new criterion for assessing discriminant validity in variance-based structural equation modeling. J. Acad. Mark. Sci. 2015, 43, 115-135. [CrossRef]

127. Fornell, C.; Larcker, D.F. Evaluating Structural Equation Models with Unobservable Variables and Measurement Error. J. Mark. Res. 1981, 18, 39-50. [CrossRef] 
128. Wetzels, M.; Odekerken-Schröder, G.; Van Oppen, C. Using PLS path modeling for assessing hierarchical construct models: Guidelines and empirical illustration. MIS Q. 2009, 33, 177-195. [CrossRef]

129. Hair, J.F.; Sarstedt, M.; Hopkins, L.; Kuppelwieser, V.G. Partial least squares structural equation modeling (PLS-SEM): An emerging tool in business research. Eur. Bus. Rev. 2014, 26, 106-121. [CrossRef]

130. Cohen, J. Set Correlation and Contingency Tables. Appl. Psychol. Meas. 1988, 12, 425-434. [CrossRef]

131. Hu, L.; Bentler, P.M. Cutoff criteria for fit indexes in covariance structure analysis: Conventional criteria versus new alternatives. Struct. Equ. Model. A Multidiscip. J. 1999, 6, 1-55. [CrossRef]

132. Henseler, J.; Ringle, C.M.; Sarstedt, M. Testing measurement invariance of composites using partial least squares. Int. Mark. Rev. 2016, 33, 405-431. [CrossRef]

133. Markovic, S.; Koporcic, N.; Arslanagic-Kalajdzic, M.; Kadic-Maglajlic, S.; Bagherzadeh, M.; Islam, N. Business-to-business open innovation: COVID-19 lessons for small and medium-sized enterprises from emerging markets. Technol. Forecast. Soc. Change 2021, 170, 120883. [CrossRef]

134. Zahra, S.A.; Covin, J.G. The financial implications of fit between competitive strategy and innovation types and sources. J. High Technol. Manag. Res. 1994, 5, 183-211. [CrossRef]

135. Barney, J. Firm resources and sustained competitive advantage. J. Manag. 1991, 17, 99-120. [CrossRef]

136. González-Velasco, C.; González-Fernández, M.; Fanjul-Suárez, J.L. Does innovative effort matter for corporate performance in Spanish companies in a context of financial crisis? A fuzzy-set QCA approach. Empir. Econ. 2017, 56, 1707-1727. [CrossRef]

137. Nicola, M.; Alsafi, Z.; Sohrabi, C.; Kerwan, A.; Al-Jabir, A.; Iosifidis, C.; Agha, M.; Agha, R. The socio-economic implications of the coronavirus pandemic (COVID-19): A review. Int. J. Surg. 2020, 78, 185-193. [CrossRef]

138. Karim, M.R.; Shetu, S.A.; Razia, S. COVID-19, liquidity and financial health: Empirical evidence from South Asian economy. Asian J. Econ. Bank. 2021, 5, 307-323. [CrossRef]

139. Al-Qirim, N. The adoption of eCommerce communications and applications technologies in small businesses in New Zealand. Electron. Commer. Res. Appl. 2007, 6, 462-473. [CrossRef]

140. Wendt, C.; Adam, M.; Benlian, A.; Kraus, S. Let's Connect to Keep the Distance: How SMEs Leverage Information and Communication Technologies to Address the COVID-19 Crisis. Inf. Syst. Front. 2021, 1, 1-19. [CrossRef]

141. Rissanen, T.; Ermolaeva, L.; Torkkeli, L.; Ahi, A.; Saarenketo, S. The role of home market context in business model change in internationalizing SMEs. Eur. Bus. Rev. 2020, 32, 257-275. [CrossRef]

142. Brem, A.; Viardot, E.; Nylund, P.A. Implications of the coronavirus (COVID-19) outbreak for innovation: Which technologies will improve our lives? Technol. Forecast. Soc. Change 2021, 163, 120451. [CrossRef]

143. Kroon, N.; Do Céu Alves, M.; Martins, I. The impacts of emerging technologies on accountants' role and skills: Connecting to open innovation-a systematic literature review. J. Open Innov. Technol. Mark. Complex. 2021, 7, 163. [CrossRef]

144. Shearmur, R.; Doloreux, D. How open innovation processes vary between urban and remote environments: Slow innovators, market-sourced information and frequency of interaction. Entrep. Reg. Dev. 2016, 28, 337-357. [CrossRef]

145. Prabowo, R.; Singgih, M.L.; Karningsih, P.D.; Widodo, E. New product development from inactive problem perspective in indonesian SMEs to open innovation. J. Open Innov. Technol. Mark. Complex. 2020, 6, 20. [CrossRef]

146. Leppäaho, T.; Ritala, P. Surviving the coronavirus pandemic and beyond: Unlocking family firms' innovation potential across crises. J. Fam. Bus. Strateg. 2021, 100440. [CrossRef]

147. Santos, E.; Tavares, V.; Tavares, F.O.; Ratten, V. How is risk different in family and non-family businesses?-A comparative statistical analysis during the COVID-19 pandemic. J. Fam. Bus. Manag. 2021, 3, 1. [CrossRef]

148. Heider, A.; Hülsbeck, M.; von Schlenk-Barnsdorf, L. The role of family firm specific resources in innovation: An integrative literature review and framework. Manag. Rev. Q. 2022, 1-48. [CrossRef]

149. van de Vrande, V.; de Jong, J.P.J.; Vanhaverbeke, W.; de Rochemont, M. Open innovation in SMEs: Trends, motives and management challenges. Technovation 2009, 29, 423-437. [CrossRef]

150. Lazzarotti, V.; Visconti, F.; Pellegrini, L.; Gjergji, R. Are there any differences between family and non-family firms in the open innovation era? Lessons from the practice of European manufacturing companies. Int. J. Technol. Intell. Plan. 2017, 11, 279-319. [CrossRef]

151. Dharmendra Chahar, D.; Professor, A. Analysis of E-Commerce and M-Commerce: Advantages, Limitations and Security issues. Int. J. Adv. Res. Comput. Commun. Eng. 2013, 2, 2360-2370.

152. Ulas, D. Digital Transformation Process and SMEs. Procedia Comput. Sci. 2019, 158, 662-671. [CrossRef]

153. Oduro, S. Examining open innovation practices in low-tech SMEs: Insights from an emerging market. J. Sci. Technol. Policy Manag. 2019, 10, 509-532. [CrossRef]

154. Muntean, M.I.; Tarnaveanu, D.; Ion, A.R. E-Commerce Performance. Shopping Cart Key Performance Indicators. Inform. Econ. 2016, 20, 62-71. [CrossRef]

155. Chang, K.C.; Jackson, J.; Grover, V. E-commerce and corporate strategy: An executive perspective. Inf. Manag. 2003, 40, 663-675. [CrossRef]

156. Ardito, L.; Messeni Petruzzelli, A.; Dezi, L.; Castellano, S. The influence of inbound open innovation on ambidexterity performance: Does it pay to source knowledge from supply chain stakeholders? J. Bus. Res. 2018, 119, 321-329. [CrossRef]

157. Carayannis, E.G.; Barth, T.D.; Campbell, D.F. The Quintuple Helix innovation model: Global warming as a challenge and driver for innovation. J. Innov. Entrep. 2012, 1, 2. [CrossRef] 
158. Abdeldayem, M.; Aldulaimi, S. Entrepreneurial finance and crowdfunding in the Middle East. Int. J. Organ. Anal. 2021. [CrossRef]

159. Ullah, F.; Degong, M.; Anwar, M.; Hussain, S.; Ullah, R. Supportive tactics for innovative and sustainability performance in emerging SMEs. Financ. Innov. 2021, 7, 80. [CrossRef]

160. De Paoli, D.; Sauer, E.; Ropo, A. The spatial context of organizations: A critique of 'creative workspaces'. J. Manag. Organ. 2019, 25, 331-352. [CrossRef]

161. Nofiani, D.; Indarti, N.; Lukito-Budi, A.S.; Manik, H.F.G.G. The dynamics between balanced and combined ambidextrous strategies: A paradoxical affair about the effect of entrepreneurial orientation on SMEs' performance. J. Entrep. Emerg. Econ. 2021, 13, 1262-1286. [CrossRef] 